\title{
Yield maximization of direct sown rice (Oryza sativa I.) under water constraint situation
}

\section{Kalyanasundaram*}

Department of Agronomy, Faculty of Agriculture, Annamalai University, Chidambaram - 608002 (Tamil Nadu) India

\section{E Arthi}

Department of Agronomy, Faculty of Agriculture, Annamalai University, Chidambaram - 608002 (Tamil Nadu) India

\section{K. P. Senthil Kumar}

Department of Agronomy, Faculty of Agriculture, Annamalai University, Chidambaram - 608002 (Tamil Nadu) India

\section{S.Harini Sri}

Department of Agronomy, Faculty of Agriculture, Annamalai University, Chidambaram - 608002 (Tamil Nadu) India

Augustine. R

Department of Agronomy, Faculty of Agriculture, Annamalai University, Chidambaram - 608002 (Tamil Nadu) India

*Corresponding author. Email: kalyankavi@rediffmail.com

\section{Article Info}

https://doi.org/10.31018/ jans.v13i1.2564

Received: February 7, 2021

Revised: March 9, 2021

Accepted: March 12, 2021

\section{How to Cite}

Kalyanasundaram, D. et al. (2021). Yield maximization of direct sown rice (Oryza sativa I.) under water constraint situation. Journal of Applied and Natural Science, 13(1): 373 - 376. https://doi.org/10.31018/jans.v13i1.2564

\begin{abstract}
More efficient water management practices need to be adopted for better sustainable rice production grown under traditional areas due to increased water scarcity. Among the different water management practices, efficient new generation water-saving chemicals and organic products were used to conserve water under field condition. An experiment was conducted to evaluate the yield maximization in direct sown CO51 rice (Oryza sativa L.) under water constraint situation. The main plot treatments comprised of three levels of irrigation viz., Conventional irrigation $\left(M_{1}\right)$, Tensiometer based irrigation $\left(M_{2}\right)$ and Deficit irrigation $\left(\mathrm{M}_{3}\right)$, respectively and were tested with four different water conservation practices in sub-plots viz., soil application of watersaving crystals (WSC) @ $5 \mathrm{~kg} \mathrm{ha}^{-1}\left(\mathrm{~S}_{1}\right)$, foliar application of drought shield @ 3 litres ha ${ }^{-1}\left(\mathrm{~S}_{2}\right)$, soil application of humic granules@ $2.5 \mathrm{~kg} \mathrm{ha}^{-1}\left(\mathrm{~S}_{3}\right)$ and soil application of FYM @ $12.5 \mathrm{t} \mathrm{ha}^{-1}\left(\mathrm{~S}_{4}\right)$. Experimental results indicated that Tensiometer based irrigation with soil application humic granules @ $2.5 \mathrm{~kg} \mathrm{ha}^{-1} \mathrm{M}_{2} \mathrm{~S}_{3}$ ) recorded higher number of panicles $\mathrm{m}^{-2}(411)$ and number of filled grains panicle ${ }^{-1}(108.16)$ in direct-sown rice. However, $\mathrm{M}_{2} \mathrm{~S}_{3}$ recorded significantly maximum grain yield (6352 kg ha-1) and minimum (3940 $\left.\mathrm{kg} \mathrm{ha}^{-1}\right)$ in $\left(\mathrm{M}_{3} \mathrm{~S}_{4}\right)$ deficit irrigation applied with FYM @12.5 t ha-1 in the year 2018 Sornavari season, respectively. Thus the Tensiometer based irrigation with soil application of humic granules @ $2.5 \mathrm{~kg}$ ha-1 can be a feasible approach for increasing grain yield and conserve water in north eastern region of Tamil Nadu, by promoting water use efficiency method in direct rice cultivation areas.
\end{abstract}

Keywords: Direct-sown rice, Irrigation, Water conservation, Yield parameters

\section{INTRODUCTION}

For millions of people in the world, particularly in Asian countries, rice is the staple food. Cultivation of rice possesses immense importance in the food security of Asia, where more than $90 \%$ of the global rice is produced and consumed. Nowadays the availability of water for irrigation is getting scarce and it is important to look into a water-efficient agriculture. (Kurrey et al.
2018). Food demand gets on increasing while the water resources are declining and are becoming challenges for food security. With diminishing water availability, increased frequency of extreme drought and high temperature events are a serious threat to the farmers, resulting in crop losses (Korres et al., 2017). Hence, rice production had to be switched towards a smart irrigation method, which involves increased rice productivity with increased water use efficiency (WUE). 
Water saving crystals in other terms, agricultural hydrogels are synthetic polymers that absorb as many times as their weight in water, which can be distributed in dry areas to improve the soil ability to absorb water (Neethu et al., 2018).

Tensiometer is a simple device which measures the amount of energy required by the plant to pull soil water at the current moisture level and thereby guides the farmers when to irrigate the crop (Kamal et al., 2018). Studies of Bhatt et al. (2016) tensiometer based irrigation application in rice would save $14-15 \%$ of water. The application of FYM resulted in improved crop growth by supplying plant nutrients, including micronutrients, which improved soil properties, thereby favouring maximum yield (Dejene and Lemlem, 2012). Drought shield protects plants from heat, water loss, drying winds, sunburn and make them stable under drought-prone condition. According to Perumal Palanivel et al. (2015), the application of humic substance in rice resulted in increased plant growth and yield characteristics significantly.

Hence a field investigation was carried out to study the effect of water conservation practices in conjunction with different levels of irrigation on the grain yield of rice (CO51) under direct-sown condition with the objective to study the influence of different levels of irrigation and water conservation practices on the yield and yield characters of direct-sown rice (CO51).

\section{MATERIALS AND METHODS}

The experiment was carried out at the Experimental Farm, Department of Agronomy, Annamalai University, to study the agronomic practices for yield maximization of direct-sown rice under water constraint situation during February to May 2018 ("Sornavari" season). Rice variety CO51 obtained from Tamilnadu Agricultural University, Coimbatore, was chosen for the study and a spacing of $15 \times 10 \mathrm{~cm}$ was adopted. The recommended dose of fertilizer RDF for rice (CO51) variety 120:40:40 $\mathrm{kg}$ of NPK ha-1 was practised.

Three replication in a Split plot design was carried out for the research. The main plot treatments were composed of three irrigation viz., $\mathrm{M}_{1}$-Conventional irrigation, $\mathrm{M}_{2}$-Tensiometer-based irrigation, and $\mathrm{M}_{3}$-Deficit irrigation. The sub-plot treatments comprised of different water conservation practices viz., $\mathrm{S}_{1}$-Soil application of water-saving crystals (WSC) @ $5 \mathrm{~kg} \mathrm{ha}^{-1}, \mathrm{~S}_{2}$-Foliar application of drought shield @ 3 litres ha ${ }^{-1}, \mathrm{~S}_{3}$-Soil application of humic granules @ $2.5 \mathrm{~kg} \mathrm{ha}^{-1}$ and $\mathrm{S}_{4}$-Soil application of FYM @ $12.5 \mathrm{t} \mathrm{ha}^{-1}$. The average water requirement for direct-sown rice in the experimental area is $920 \mathrm{~mm}$. Under conventional irrigation, the crop was irrigated with $5 \mathrm{~cm}$ of water each time 3 days after the disappearance of applied water throughout the crop duration. In Tensiometer based irrigation, the crop was irrigated upto the field capacity (tensiometer value of 0.7 ) and in deficit irrigation, the crop was irrigated to a medium level of Available soil moisture (ASM) with a tensiometer value of 0.5 . Irrigation was scheduled at the vegetative phase, reproductive phase, ripening phase. The number of irrigations given under the main plots was scheduled as follows: Conventional irrigation -23 , Tensiometer based irrigation - 17 and Deficit irrigation -12 , respectively. Observations on the number of panicles $\mathrm{m}^{-2}$, number of filled grains panicle $e^{-1}$, Grain yield and straw yield were recorded.

The data obtained from various observations were statistically analyzed as the split-plot design procedure using the standard techniques of Analysis of Variance (ANOVA) as suggested by Gomez and Gomez (1984). The critical difference at $5 \%$ level of probability was calculated for testing the significance of the difference between any two means wherever ' $F$ ' test was found significant. Wherever the calculated 'F-value' exceeded the tabulated value, the difference between the treatments was significant.

\section{RESULTS AND DISCUSSION}

\section{Effects of irrigation and water conservation practices on yield parameters:}

Number of panicles $\mathrm{m}^{-2}$ and filled grains panicle ${ }^{-1}$ : Among the irrigation practices adopted, Tensiometer based irrigation $-M_{2}$, recorded the maximum number of panicles $\mathrm{m}^{-2}$ (368) and number of filled grains panicle ${ }^{-1}$ (96.06). Availability of adequate water to the crop and enough aeration at critical growth stages of direct sown rice resulted in maximum yield components (Table 1).

Among the water conservation practices scheduled, soil application of humic granules @ $2.5 \mathrm{~kg} \mathrm{ha}^{-1}$ on 30 and 45 DAS had recorded the maximum number of panicles $\mathrm{m}^{-2}$ (382) and number of filled grains panicle ${ }^{-1}$ (100.05) in direct-sown rice. This might be due to higher nutrient uptake, particularly phosphorous, which might have enhanced the grain filling in direct sown rice. Similar higher results were obtained in the studies of Saha et al. (2013) by incorporating Humic acid (HA) @ 6Lha-1 in T. aman rice cv. BRRI dhan 39. The treatment combination $\mathrm{M}_{3} \mathrm{~S}_{4}$ (Deficit irrigation applied with FYM @ $12.5 \mathrm{t} \mathrm{ha}^{-1}$ ) recorded the minimum yield components which might be due to water stress in plants at grain filling stage.

\section{Yield}

Water management practices played a major role in influencing the grain and straw yield of direct sown rice. $\mathrm{M}_{2}$-Tensiometer based irrigation recorded the maximum grain yield $\left(5524 \mathrm{~kg} \mathrm{ha}^{-1}\right)$ and straw yield $(6849 \mathrm{~kg}$ $\left.\mathrm{ha}^{-1}\right)$. The increased yield might be due to the effective utilization of water throughout the crop growth, especially at critical growth stages (Fig. 1). Similarly, Kumar 
Table 1. Effects of different levels of irrigation and water conservation practices on yield and yield parameters ha ${ }^{-1}$ of direct-sown CO 51 rice .

\begin{tabular}{|c|c|c|c|c|c|}
\hline Treatments & $\begin{array}{l}\text { Number of } \\
\text { panicles } \\
m^{-2} \text { (nos.) }\end{array}$ & $\begin{array}{l}\text { Number of filled } \\
\text { grains panicle }{ }^{-1} \\
\text { (nos.) }\end{array}$ & $\begin{array}{l}\text { Grain } \\
\text { yield } \\
\left(\mathrm{kg} \mathrm{ha}^{-1}\right)\end{array}$ & $\begin{array}{l}\text { Straw } \\
\text { yield } \\
\left(\mathrm{kg} \mathrm{ha}^{-1}\right)\end{array}$ & $\begin{array}{l}\text { Harvest } \\
\text { index }\end{array}$ \\
\hline $\mathrm{M}_{1}-$ Conventional irrigation & 364 & 95.74 & 5438 & 6765 & 44.53 \\
\hline$M_{2}-$ Tensiometer based irrigation & 368 & 96.06 & 5524 & 6849 & 44.52 \\
\hline$M_{3}$ - Deficit irrigation & 318 & 82.09 & 4497 & 5895 & 43.23 \\
\hline S. Ed & 2.53 & 0.66 & 38.90 & 47.02 & NS \\
\hline C.D $(p=0.05)$ & 7.03 & 1.85 & 108.02 & 130.55 & NS \\
\hline$S_{1}-$ Soil application of water saving crys- & 352 & 91.83 & 5158 & 6553 & 43.98 \\
\hline $\mathrm{S}_{2}$ - Foliar application of drought shield@ 3 & 354 & 92.54 & 5290 & 6604 & 44.42 \\
\hline $\begin{array}{l}\mathrm{S}_{3}-\text { Soil application of humic granules @ } \\
2.5 \mathrm{~kg} \mathrm{ha}^{-1}\end{array}$ & 382 & 100.05 & 5779 & 7111 & 44.76 \\
\hline $\mathrm{S}_{3}$ - Soil application of FYM @ $12.5 \mathrm{t} \mathrm{ha}^{-1}$ & 312 & 80.76 & 4385 & 5743 & 43.24 \\
\hline S. Ed & 4.19 & 1.09 & 63.66 & 78.38 & NS \\
\hline C.D $(p=0.05)$ & 8.82 & 2.31 & 133.76 & 164.68 & NS \\
\hline
\end{tabular}

\section{Water use efficiency in rice}

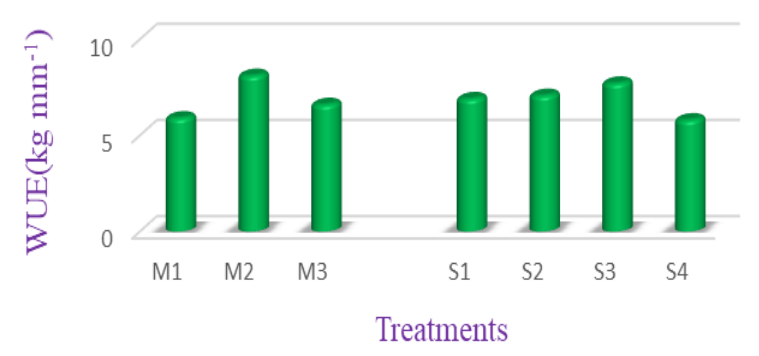

Fig 1. Water use efficiency in different levels of irrigation and water conservation practices in $M-$ as main plots and $S$ - as sub-plot treatments.

et al. (2017) reported in four rice varieties (Apo, Annada, Satabdi and Naveen) that improved grain yield has happened due to the adoption of water deficit irrigation strategy with an appropriate irrigation threshold can save water and increase water productivity.

Among the water conservation practices, $S_{3^{-}}$Humic granule @ $2.5 \mathrm{~kg} \mathrm{ha}^{-1}$ on 30 and 45 DAS recorded the maximum grain yield of $5779 \mathrm{~kg} \mathrm{ha}^{-1}$ and straw yield of $7111 \mathrm{~kg} \mathrm{ha}^{-1}$. This might be due to increased uptake of nutrients, improved aeration and water holding capacity of soil in the humic acid applied treatment. Enhanced uptake of nutrients was evident in the present study could have exerted beneficial effects on growth and yield components of direct-sown rice. Similar findings were observed by Saha et al. (2013) in BRRI dhan 39 with HA $6 \mathrm{~L} \mathrm{ha}^{-1}$ and El-Gohary et al. (2010) in rice plants with foliar application of humic @ $5 \mathrm{~g} / \mathrm{L}$ in Giza, Egypt. This was followed by foliar application of drought shield @ 3 liters ha ${ }^{-1}\left(\mathrm{~S}_{2}\right)$ with a value of $5290 \mathrm{~kg} \mathrm{ha}^{-1}$. Mitali et al. (2017) reported that grain yield was highest at Tensiometer based irrigation at $35 \mathrm{~cm}$ depth with 50 $\mathrm{kPa}$ tension and lowest at $20 \mathrm{~cm}$ depth with $20 \mathrm{kPa}$ tension in 2013-14 and grain yield was highest at Tensiometer at $35 \mathrm{~cm}$ depth with $50 \mathrm{kPa}$ tension in 201415.

In the present study, the interaction between different levels of irrigation and water conservation practices influenced the grain yield of direct-sown rice. The maximum grain yield was recorded in the treatment combination $\left(\mathrm{M}_{2} \mathrm{~S}_{3}\right)$ Tensiometer based irrigation along with soil application of humic granules @ $2.5 \mathrm{~kg} \mathrm{ha}^{-1}$ on 30 and 45 DAS. The increased yield might be due to the availability of adequate nutrients and soil moisture during the physiological growth stages, thereby providing favourable conditions for the crop to express its maximum yield potentiality.

\section{Conclusion}

We found that Tensiometer based irrigation with soil application of humic granules was highly responsive to direct-sown rice (CO51). This unique treatment has resulted in higher number of panicles $\mathrm{m}^{-2}$, number of filled grains panicle-1, grain yield and straw yield than conventional and deficit irrigation with other subplot treatments. Since the conventional and deficit irrigation with other subplot treatments offered no significant yield advantages over the Tesniometer based irrigation, we recommend the tensiometer meter + HA granules @ 2.5 kgha-1 in the soil to hasten the direct-sown rice productivity. These results indicated that Tensiometer based irrigation with soil application of humic gran- 
ules was a feasible and practical means of increasing grain yield under water constraint situations and water use efficiency of direct sown rice (CO51) in north eastern regions of Tamil Nadu.

\section{Conflict of interest}

The authors declare that they have no conflict of interest.

\section{REFERENCES}

1. Bhatt, R., S. Arora and C. C. Chew (2016). Improving irrigation water productivity using Tensiometers. J. of Soil and Water Conservation, 15(2), 120-124.

2. Dejene, M. and M. Lemlem. (2012). Integrated agronomic crop managements to improve productivity under terminal drought, water stress. In Tech. open Sci., 235-254.

3. El-Gohary, A., Osman, E., Khatab, K. (2010). 'Effect of nitrogen fertilization, humic acid and compost extract on yield and quality of rice plants', Journal of Soil Sciences and Agricultural Engineering, 1(1), 77 $-91$

4. Gomez, K.A. and A. A. Gomez (1984). Statistical procedure for agricultural research. II edn. John Wiley and Sons, New York, 680p.

5. Kamal Vatta, R. S. Sidhu, Upmanu Lall, P. S. Birthal, Garima Taneja, Baljinder Kaur, Naresh Devineni and Charlotte MacAlister (2018) Assessing the economic impact of a lowcost watersaving irrigation technology in Indian Punjab: the Tensiometer, Water International, 43, 2, 305-321.

6. Korres, N. E., Norsworthy, J. K., Burgos N.R. and Oosterhuis D. M. (2017). Temperature and drought impacts on rice production: an agronomic perspective regarding short- and long-term adaptation measures. Water Resources and Rural Development, 9: 12-27.

7. Kumar, A., Nayak, A.K., Pani, D.R. and Das, B.S. (2017). Physiological and morphological responses of four different rice cultivars to soil water potential based deficit irrigation management strategies. Field Crops Research, 205, 78-94.

8. Kurrey, D., Singh, R.K. and Rajput, R. S. (2018). Effect of hydrogel and Trichoderma on root growth and water productivity in Rice varieties under rainfed conditions. Research Journal of Agricultural Sciences, 9, 210-212.

9. Mitali, K. Sah, K. P. Bhurer, Pradeep Shah, Tufail Akhtar, Mathura Yadav and Rumesh

10. Ranjan. 2017. Irrigation scheduling in wheat using Tensiometer at Bara district of Nepal. Chem. Sci. Rev. Lett., 6 (22), 710-714.

11. Neethu, T.M., Dubey, P.K. and Kaswala, A.R. (2018). Prospects and Applications of Hydrogel Technology in Agriculture. Int. J. Curr. Microbiol. App. Sci, 7(5), 3155-3162.

12. Perumal Palanivell, Osumanu Haruna Ahmed, Nik Muhamad Ab Majid, Mohamadu Boyie Jalloh and Kasim Susilawati. (2015). Improving lowland rice (Oryza sativa cv. MR219) Plant Growth Variables, Nutrients Uptake, and Nutrients Recovery Using Crude Humic Substances. The Scientific World J., 1, 14.

13. Saha, R., M.A.U. Saieed and M.A.K. Chowdhury. (2013). Growth and yield of rice (Oryza sativa) as influenced by humic acid and poultry manure. Universal J. of Plant Sci., 1(3),78-84. 